CENDEKIA, Vol. 9, No. 1, April 2015

p ISSN: 1978 2098; e ISSN: 2407 8557; Web: cendekia.pusatbahasa.or.id

Pusat Kajian Bahasa dan Budaya, Surakarta, Indonesia

Hendriani, Dita. 2015. Pendidikan Sejarah, Sebuah Tinjauan Metodologi.

Cendekia, 9(1): 95 102.

\title{
PENDIDIKAN SEJARAH, SEBUAH TINJUAN METODOLOGI
}

\author{
Dita Hendriani \\ IAIN Tulungagung \\ Jl. Mayor Sujadi Timur 46 Tulungagung, Jawa Timur \\ E-mail: hendrianidita@gmail.com
}

\begin{abstract}
This paper presents conceptual description on historical education in the methods of historical discovery using library analyses. The analyses indicate that (1) historical events can be described through two empirical facts: written and oral. Conventional history accostomes only written facts; in addition, oral facts that tend to be accepted as the complimentary materials support the written facts delineating a crosscheck process to achieve the truth, (2) historical narration shoulb be clear-cut from tales; tales are produced by non-historian mixing facts and arts that should not be based on historical data, rather the author's imagination, (3) phylosophy history is much written by non-historican but experts on phylosophy, and (4) history with Indonesian perspectives is significant to explore, hiwever much of the histiry is considered military oriented.
\end{abstract}

Keywords: history education, methods of historical discovery.

Seorang penulis Argentina bernama Jorge Luis Borges menulis sebuah karya prosa fiksi berjudul Funes The Memorius. Prosa tersebut, melalui penceritaan orang pertama, memusatkan perhatian pada satu orang unik bernama Funes. Dikisahkah, si bocah Funes memiliki daya ingat yang sangat luar biasa. Funes akan selalu ingat warna langit dan bentuk awan pada jam tertentu pada hari tertentu. Funes akan selalu ingat gambar samak buku yang menampilkan corak urat pada batu pada pertama kali dibeli, hingga pada bagian yang paling detail.

Kemampuan Funes ini merupakan keajaiban ingatan seperti halnya yang dipunyai oleh raja Cyrus dari Persia yang mampu mengingat masing-masing nama prajuritnya di luar kepala, atau Metrodorus yang mengulangi dengan setia apapun yang pernah didengarnya. Di sisi lain, kelemahan dari Funes adalah ia tidak mampu membuat persamaan-persamaan dan perbedaan dari satu benda di waktu yang berbeda. Baginya sebuah batu pada jam sebelas siang akan berbeda dengan batu itu pada pukul sebelas lebih satu detik. Ia dapat mengingat masa lalu, tapi tidak bisa membuat kaitan antara benda atau kejadian di masa lalu dengan masa berikutnya (Borges, 1999:136-148).

Jika dikaitkan dengan sejarah, apakah ingatan Funes mengenai sebuah batu di suatu waktu di masa lalu merupakan pengetahuan sejarah? Menurut Kuntowijoyo (2003), sejarah dibedakan dengan ilmu lainnya berdasarkan atas fokusnya pada diakroni fakta-fakta yang dikaji. Pengetahuan Funes mengenai sebuah batu di waktu A misalnya, bukanlah sejarah, melainkan pengetahuan ilmiah semata. 


\section{METODE}

Studi ini menggunakan metode kepustakaan. Data primer dikumpulkan dengan mengacu pada sumber bacaan up to date, relavan, dan berbobot ilmiah tinggi. Metode literatur ini menekankan data baik dari buku, e-book, jurnal, e-journal, internet, glogger, berita dari surat kabar elektronik, majalah, e magazine, koran, dan data dokumentasi lainnya. Analisis lebih menekankan analisis isi atas hasil bacaan yang dilakukan dengan mengacu pada teori yang paling sesuai, paling kuat, paling rasional, dan paling up to date. Diskusi dengan ahli, baik sesama dosen internal kampus, dosen eksternal kampus, maupun dengan kolega yang dianggap mumpuni di bidang ini merupakan upaya yang telah dilakukan demi kesempurnaan kajian/studi ini. Hasil akhir seluruh proses panjang di atas, menjadilah sebuah hasil kajian yang mempunyai bobot akademik, dan layak untuk dipublikasikan.

\section{HASIL DAN BAHASAN}

\section{Konsep Sejarah}

Sejarah adalah mengerti sebuah peristiwa atau benda dan perjalanannya melintasi waktu. Pengetahuan tentang sebuah bangku dikatakan sejarah apabila memenuhi aspek-aspek pengetahuan mengenai masa lalu bangku tersebut, darimana bangku itu berasal, dibuat dari bahan apa, siapa pembuatnya, bagaimana cara kita mendapatkannya, harga yang harus dikeluarkan untuk mendapatkannya, berapa lama bangku tersebut kita miliki, bagaimana arti sebuah bangku semacam itu dalam lintasan waktu, dan seterusnya.

Pengetahuan mengenai cara pembuatan bangku atau harga sebuah bangku pada minggu yang lalu dikatakan bukan merupakan pengetahuan sejarah apabila pengetahuan tersebut hanya bertitik pada harga di satu waktu saja, dalam arti tidak mempersoalkan waktu sebagai proses. Pengetahuan Funes mengenai sebuah samak buku saat ini bukanlah sejarah, karena ia tidak mampu menjelaskan bagaimana buku tersebut dari berwarna coklat hingga kemudian berwarna pudar.

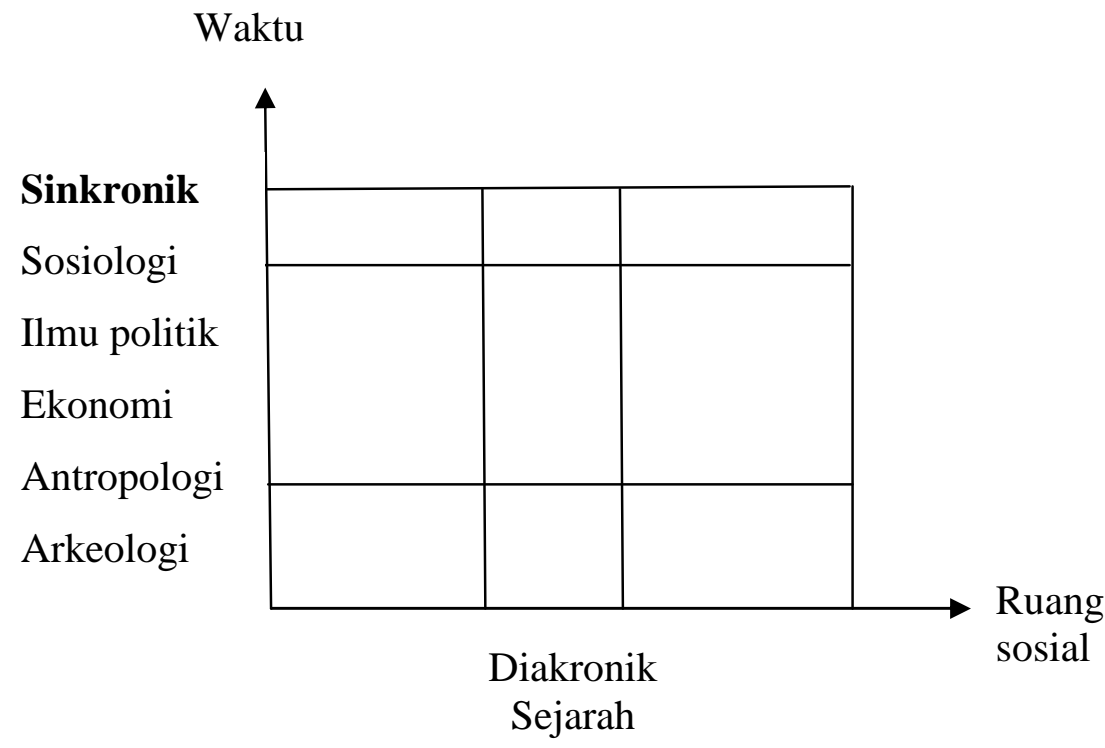

Diagram 1. Perbedaan Sejarah dengan Ilmu Lainnya 
CENDEKIA, Vol. 9, No. 1, April 2015

p ISSN: 1978 2098; e ISSN: 2407 8557; Web: cendekia.pusatbahasa.or.id

Pusat Kajian Bahasa dan Budaya, Surakarta, Indonesia

Hendriani, Dita. 2015. Pendidikan Sejarah, Sebuah Tinjauan Metodologi.

Cendekia, 9(1): 95 102.

Sejalan dengan Kuntowijoyo, Lemon (1995) menganggap bahwa sejarah adalah pengetahuan mengenai masa lalu, bukan masa depan. Persoalan utama yang dihadapi sejarawan adalah bagaimana ia mengungkap masa lalu. Lemon menganjurkan bahwa sebuah pengetahuan sejarah dapat menempatkan masa kini sebagai sebuah bukti faktual dari sesuatu yang kemudian dicari/ diungkap realitas sejarahnya. Dengan demikian, sejarah bukanlah sebuah peristiwa di satu waktu di masa lalu, melainkan suatu peristiwa di masa lalu dalam durasi tertentu, dalam ruang diakronik. Sementara pengetahuan nonsejarah adalah sebuah peristiwa di satu waktu saja, sinkronik.

Pengetahuan ilmiah yang sinkronik mempunai kedalaman, rincian, detail yag tidak dipunyai oleh pengetahuan sejarah. Dalam hal ini pengetahuan sinkonik akan membantu disiplin sejarah dalam mamahami suatu subyek sejarah. Toeri-teori, pendekatan-pendekatan, dan hasil-hasil penyelidikan ilmu sinkronik itu akan membantu sejarawan ketika menyelidiki satu persoalan. Dalam lapangan ilmu sinkronik terdapat studi yang membandingkan satu kasus di waktu lampau dan kini, struktur sosial masyarakat di kota Bandung tahun 1967 dibandingkan tahun 1998 misalnya, tetapi berbeda dengan sejarah ia tidak menguraikan bagaimana perubahan itu terjadi, hal-hal apa yang membuatnya berubah, apa saja yang memegang peranan penting, agen-agenya, dan sebagainya. Ilmu sinkronik hanya membuat perbedaan-perbedaan persamaan-persamaan saja.

Persoalan ruang dan waktu, sinkronik dan diankronik, dalam sejarah dapat menghasilkan satu model-model dalam penelitian sejarah. Kuntowijoyo menyebutkan, ada hal mengenai sejarah yang ditempatkan pada ruang sosial, meski pada hemat saya bisa juga diterapkan pada obyek/subyek sejarah yang lain. Pertama yaitu evolusi, penelitian sejarah semacam ini menempatkan sebuah rentang dengan satu unsur persoalan sebagai benang merahnya. Sebagai contoh adalah kesenian ludruk diteliti mulai dari berdirinya, pengaruhpengaruh yang didapatkan, bentuk-bentuk lakon, dan sebagainya. Lemon menganjurkan agar menempatkan masa kini, atau masa akhir, sebagai bukti yang menjadi patokan evolusi dari satu peristiwa sejarah.

Kuntowijoyo menunjukan bagaimana sejarah dapat meminjam teori-teori dan modelmodel yang ada pada ilmu sosial atau ilmu eksakta untuk membantu penyelidikan sejarah. Ia juga menunjukan bagaimana variasi dan kedalaman penyelidikan sejarah ditentukan oleh kapasitas sejarawan yang meneliti. Penelitian-penelitian sejarah yang banyak melibatkan ilmu di luar sejarah sebagian besar dilakukan oleh orang yang secara formal tidak belajar sejarah. Orang-orang di luar sejarah ini kemudian menyelidiki satu peristiwa dengan kerangka pendekatan yang dimilikinya, dengan menempatkan sebuah durasi waktu yang mengakibatkan hasil penyelidikannya akan bersifat penyelidikan sejarah.

Faktor yang paling banyak menyumbang sejarah yang tidak ditulis oleh sejarawan adalah sejarah biografi, yang meski tidak memiliki metode dan pendekatan yang ketat, tetapi secara sadar ditulis sebagai sebuah narasi sejarah. Sejarah sosial barangkali merupakan narasi sejarah yang paling awal yang melibatkan ilmu non sejarah dalam penyelidikan sejarah. Dalam sejarah Indonesia, sejarah ekonomi merupakan bidang sejarah yang paling sedikit ditulis. Pemahaman sejarawan akan ilmu ekonomi dan sedikitnya peran ahli-ahli ekonomi dalam penyelidikan sejarah bisa jadi merupakan faktor penunjang sedikitnya hasil penyelidikan sejarah ekonomi. 
CENDEKIA, Vol. 9, No. 1, April 2015

p ISSN: 1978 2098; e ISSN: 2407 8557; Web: cendekia.pusatbahasa.or.id

Pusat Kajian Bahasa dan Budaya, Surakarta, Indonesia

Hendriani, Dita. 2015. Pendidikan Sejarah, Sebuah Tinjauan Metodologi.

Cendekia, 9(1): 95 102.

Pelibatan teori-teori dan model-model ilmu nonsejarah pada gilirannya akan membantu perluasan bidang kajian sejarah. Meneliti sejarah tentang satu masyarakat tentu akan lebih mudah apabila menggunakan bantuan teori-teori dan model-model yang ada dalam ilmu sosiologi atau antropologi, atau mencampurnya. Dengan demikian, salah satu tantangan nyata dan permasalahan yang substansial dalam ilmu sejarah adalah mengkombinasikan praktik sejarawan dengan usaha-usaha untuk memperkenalkan cabang-cabang baru dari disiplin ilmu ini, misalnya sejarah sosial atau sejarah wanita. Hal yang mendasari ketidaksenangan para sejarawan konvensional terhadap cabang-cabang baru studi sejarah adalah tidak adanya refleksi, kepentingan, relevansi, atau signifikansi, yang mengakibatkan problematisasi terhadap persoalan yang dihadapi menjadi terbatas.

\section{Bukti Sejarah dan Keabsahannya}

Peristiwa sejarah dapat diungkapkan melalui dua macam bukti, yaitu bukti tertulis dan bukti lisan. Sejarah konvensional mengenal hanya bukti tertulis yang dianggap mempunyai validitas yang bisa dipercaya. Sejarah semacam ini mengakibatkan hasil penyelidikan sejarah akan menjadi kaku, dan hanya mewakili kepentingan-kepentingan dan peristiwa-peristiwa yang bisa jadi kebetulan ditulis.

Dalam perkembangan selanjutnya, sejarawan melirik pada bukti-bukti lisan sebagai salah satu unsur penting dalam penyelidikan sejarah. Sejarah lisan tersebut akan memberikan petunjuk pada fakta-fakta sejarah yang tidak atau kebetulan tidak ditulis. Kesaksian-kesaksian ini tidak seperti dokumen yang kering, akan memberikan nuansa yang lebih hidup. Polemik mengenai siapa sebenarnya penggagas Pancasila, apakah Soekarno atau Moh. Yamin, ternyata banyak dibantu oleh kesaksian dari pada peserta rapat BPUPKI, sementara bukti tertulis yang disusun M. Yamin memang dibuat berdasar kepentingannya.

Persoalan penting yang dihadapi bukti adalah validitasnya. Supersemar, adalah salah satu contoh bukti tertulis yang sampai saat ini masih diragukan keabsahannya.. Banyak pihak yang meragukan keasliannya, meski terdapat tanda tangan Soekarno (oleh banyak pihak dianggap palsu). Sejarah lisan pun menghadapi persoalan validitas data. Kebohongan dari saksi mata, kekuatan ingatan yang tidak sekuat tulisan, menjadi hal-hal yang harus dicermati oleh sejarawan.

Mekanisme check, recheck, dan cross check menjadi penting, agar pendapat yang ditemukan lebih mendekati kebenaran. Check adalah proses pencari kebenaran atau kevalidan bukti sejarah dengan cara menggunakan metode yang berbeda. Contoh metode wawancara dicek dengan metode dokumentasi. Recheck adalah upaya mencari validitas data sejarah dengan melakukan metode yang sama dalam mendapatkan data sejarah. Misalnya, data sejarah dari wawancara dapat direcheck dengan wawancara juga dengan orang yang sama pada waktu yang berlainan. Sedangkan cross check merupakan upaya mencari kebenaran data sejarah dengan cara melakukan wawancara ulang dengan orang yang berbeda baik waktu dan tempat yang bersamaan maupun waktu dan tempat yang berbeda (Busro, 2015).

Aspek yang perlu diperhatikan juga adalah adanya tradisi lisan, yang darinya dapat diketahui nilai-nilai, sejarah, moral, struktur sosial, yang ada dalam satu masyarakat. Buktibukti yang didapatkan harus bisa dikombinasikan sedemikian rupa, dan tidak boleh mengandung kontradiksi di dalamnya. 
CENDEKIA, Vol. 9, No. 1, April 2015

p ISSN: 1978 2098; e ISSN: 2407 8557; Web: cendekia.pusatbahasa.or.id

Pusat Kajian Bahasa dan Budaya, Surakarta, Indonesia

Hendriani, Dita. 2015. Pendidikan Sejarah, Sebuah Tinjauan Metodologi.

Cendekia, 9(1): 95 102.

Tradisi lisan yang sudah turun temurun memang berpeluang untuk bergeser dari satu generasi ke genarasi berikutnya, akan tetapi para penutur tradisi lisan dalam hal ini masyarakat asli pemilik tradisi lisan tersebut jumlahnya tidak sedikit, sehingga dapat dilakukan cross check. Dengan demikian, orisinalitas sejarah lisan yang berkembang di masyarakat pemilik tidak mengalami degradasi atau kemunduran (Busro, 2015).

Tradisi lisan yang sudah berkembang, dalam perspektif akademik, tentu akan ditulis oleh para sejarawan yang nantinya akan mengubah tradisi lisan itu menjadi sejarah tertulis dengan sumber sejarah para masyarakat aslik atau masyarakat pemilik sejarah itu (Busro, 2015).

\section{Penulisan Sejarah}

Narasi sejarah harus dibedakan dengan cerita. Kuntowijoyo menyebutkan bahwa sejarah pribadi, karena ditulis oleh bukan sejarawan, banyak ditulis dengan mencampur antara fakta dengan seni. Menurut Lemon, cerita sejarah harus dibedakan cerita pada umumnya. Cerita umum merupakan narasi yang tidak harus berdasarkan data-data, tetapi yang paling utama adalah imajinasi penulisnya. Sementara narasi sejarah merupakan cerita yang bergerak berdasarkan data-data yang saling berkait menjalin cerita. narasi sejarah juga harus dibedakan dengan kronik, karena kronik bercerita berdasar tanggal/ kalender, jadi bukan berdasar atas data yang menjalin kisah.

Narasi/ pengkisahan fakta dibangun untuk tujuan yang sama, yaitu mengajak pembaca/ penikmat cerita untuk menangkap pesan yang disampaikan oleh penulis. Sebuah sebuah tinjauan narasi dimasa lalu mungkin dibangun dari fakta (lebih dari sekedar bayangan atau keinginan pikiran), tetapi sebuah cara yang jelas ataupun tersembunyi dengan tujuan mempengaruhi pembaca/ audien untuk mengadopsi sudut pandang baik secara moral maupun politik. Sebuah narasi, dengan teknik-tekniknya mampu membuat fakta-fakta tidak terungkap secara gamblang, atau bahkan memasukkan ideologi yang secara tak sadar akan disetujui oleh pembaca.

Konstruksi sebuah narasi/ kisah meliputi seleksi dan kemudian pemilahan dari peristiwa. Dengan cara demikian, ketidakmampuan untuk menyatakan secara jelas cerita yang ada menentukan tujuan dari aktifitas narasi. Narasi akan mewujudkan rasionalitas (tidak seperti kronik, walaupun harus menjadi motif dalam menghasilkan logika dari bangunan terkini, atau murni 'alasan' abstrak dan formal). Fakta yang dikisahkan adalah cerita yang memiliki sudut pandang untuk menghasilkan tujuan praktis, komunikasi yang mempengaruhi 'pesan' yang ingin disampaikan.

Pemilihan fakta akan bergantung pada perspektif, teori, dan kepentingan penulisnya. Perspektif, teori, atau kepentingan akan menentukan fakta mana yang akan diambil diberi tekanan, dikedepankan, dan fakta-fakta mana yang akan diabaikan atau disinggung selintas lalu. Fakta-fakta yang diberi nilai, entah kepentingan atau perspektif tertentu, akan menjadi peristiwa-peristiwa yang terjalin dalam narasi sejarah. Membangun sebuah kepentingan dalam narasi, harus dengan sengaja menyeleksi dan mengabaikan peristiwa-peristiwa yang kurang penting.

Beberapa tujuan atau alasan harus ditentukan oleh proses ini. Pengkisahan fakta sering didapat dengan tujuan-tujuan praktis sehingga kisah yang disajikan 'hanya' bersifat sangat 
CENDEKIA, Vol. 9, No. 1, April 2015

p ISSN: 1978 2098; e ISSN: 2407 8557; Web: cendekia.pusatbahasa.or.id

Pusat Kajian Bahasa dan Budaya, Surakarta, Indonesia

Hendriani, Dita. 2015. Pendidikan Sejarah, Sebuah Tinjauan Metodologi.

Cendekia, 9(1): 95 102.

subjektif, berpihak pada sudut pandang tertentu dan disalah artikan jauh dari kebenaran. Obyektifitas yang didominasi oleh tujuan praktis penulis narasi mendorong adanya seleksi dan peringkasan/ pemotongan narasi. Narasi dalam bentuk fakta harus dapat menyajikan kisah-kisah berdasarkan kejadian yang sebenarnya terjadi, proses observasi dan diperkuat dari berbagai macam sumber yang dapat dipercaya.

Faktor yang membedakan sejarah dengan ilmu yang lain adalah perubahan sebagai pusat perhatian, oleh karena itu sebuah narasi harus mampu mneyajikan perubahan dengan runtut. Perubahan dalam sebuah peristiwa akan menjadikan segala sesuatu menjadi berbeda. Sesuatu yang berbeda belum tentu sebuah perubahan dan perubahan tidak selalu menimbulkan perbedaan karena perubahan tidak identik dengan perbedaan. Ketika sesuatu berbeda dari sesuatu yang lain, maka waktu menjadi tidak relevan. Ketika segala sesuatu berubah, sekalipun waktu dan kontinuitasnya berasal dari identitas tunggal, waktu menjadi sangat relevan.

Kisah yang terus berlangsung adalah hasil penelusuran dari konsep-konsep yang mengandung perbedaan, perubahan, identitas dan kontinuitas. Kontinuitas adalah kondisi yang membutuhkan pemahaman dan kontinuitas sendiri menghasilkan permintaan terhadap sebuah identitas atau 'subjek' yang harus kembali kepada perubahan.

Narasi adalah struktur pada apa yang terjadi kemudian. Relevansi/ kesesuaian adalah pesan untuk membangun narasi 'kemudian'. Narasi menghubungkan struktur dasar 'ini terjadi kemudian itu terjadi' atau 'peristiwa ini kemudian peristiwa itu'. Jika hal tersebut tidak terjadi, maka narasi hanyalah isapan jempol belaka. Narasi adalah rangkaian, bukan menceritakan satu hal yang terjadi, narasi tidak menjelaskan bagian-bagian dari peristiwa, lebih dari itu, narasi menjelaskan sesuatu yang bermakna, menawarkan kejadian secara berurutan dalam sebuah cara yang dapat dimengerti.

\section{Sejarah Pemikiran}

Sebuah bidang sejarah yang paling banyak ditulis oleh bukan sejarawan barangkali adalah sejarah pemikiran. Sejarah filsafat lebih banyak ditulis oleh orang yang bukan sejarawan, tetapi ahli filsafat. Demikianlah kita menemukan sejarah filsafat barat yang ditulis Kees Bertens, seorang dosen filsafat STF Driyarkara, bukannya seorang ahli sejarah. Jakob Sumardjo, seorang sarjana seni, banyak sekali menuliskan sejarah kesenian Indonesia. Meski demikian karena tidak ditulis oleh sejarawan, banyak syarat-syarat kunci untuk menulis sejarah banya tidak ditemui dalam karya-karya Jakob Sumardjo. Kejelasan sumber, variasi sumber, hingga banyaknya data yang tidak dapat dipertanggung-jawabkan.

Sejarah filsafat lebih banyak ditulis oleh orang yang bukan sejarawan, tetapi ahli filsafat. Sejarah pemikiran pada dasarnya dapat dibagi menjadi pemikiran sebagi kerja individu dan pemikiran sebagai tradisi lisan yang diwariskan secara turun temurun. Sejarah pemikiran individu akan melihat pengaruh-pengaruh yang kemudian membentuk sebuah pemikiran pada seseorang atau melihat perkembangan sebuah pemikiran dari seseorang dan bentuknya pada kuru waktu tertentu. Seperti yang diucapkan Karl Proper, pemikiran seperti halnya bayi, akan tumbuh dan berkembang, dan pada gilirannya mungkin akan sangat berbeda dibandingkan ketika pemikrian tersebut dirumuskan. Menjadi tugas dari sejarawan untuk 
CENDEKIA, Vol. 9, No. 1, April 2015

p ISSN: 1978 2098; e ISSN: 2407 8557; Web: cendekia.pusatbahasa.or.id

Pusat Kajian Bahasa dan Budaya, Surakarta, Indonesia

Hendriani, Dita. 2015. Pendidikan Sejarah, Sebuah Tinjauan Metodologi.

Cendekia, 9(1): 95 102.

menentukan batas masa kini dan kemudian merunut kebelakang riwayat sebuah pemikiran. Ireferensi)

\section{Sejarah Nasional dan Kabut Sejarah}

Dalam bab pertama buku Klasik Kitcsh, kontemporer, Jenifer Lindsay (1989:21-22) menengarai adanya arus utama yang menjadikan seni dan kebudayaan Indonesia sebagai sesuatu yang sudah lewat dan antik. Sehingga tulisan-tulisan yang dihasilkan oleh orientalis awal tersebut akan lebih terasa cita rasa romantiknya, dan secara konseptual menganggap seni dan kebudayaan hanya sebagai benda. Hal tersebut dapat dimengerti dengan menyadari bahwa seni dan kebudayaan Indonesia pertama-tama bukan ditulis oleh orang yang berlatarbelakang pendidikan formal yang sama dengan bidang yang dikaji. Selain itu karya-karya ilmiah yang ada pada mulanya ditulis sebagai kepentigan kolonial, dan konsumsi masyarakat eropa. Sejarah Indonesia juga menghadapi hal yang sama. Sejarah indonesia hingga kini menempatkan pahlawan-pahlawan nasional berdasarkan tokoh-tokoh yang dikenal oleh kolonial Belanda karena perlawanannya.

Keinginan untuk menulis sejarah nasional muncul ketika menulis toward indonesia centrisme historiography. Sejarah berperspektif Indonesia ini dianggap penting karena hubungan ilmu dan kepentingan akan menentukan bentuk, metode, dan pada akhirnya hasil penyelidikan. Kuntowijoyo dengan halus menyebutkan sejarah nasional Indonesia ditengarai bercorak militer, A.H. Nasution yang berinisiatif membuat sejarah versi militer dengan yang kemudian diselesaikan oleh Nugroho Notosusanto. Proyek-proyek militer dalam mengkonstruksi sejarah didasari kepentingan untuk dianggap sebagai faktor utama dalam mempersatukan negara dan bangsa. Kepentingan tersebut didukung oleh birokrasi militer yang Ekakarma, yaitu kesatuan antara ABRI dengan rakyat, kesatuan antar angkatan-angkatan di lingkungan ABRI, dwi fungsi ABRI konsepsi tentang Sapta Marga, dan sebagainya, yang membatasi dan mengarahkan sejarawan militer, Sejarawan tidak menulis dengan mengedepankan kepatuhan terhadap ilmu sejarah, melainkan dengan mengkonstruksi sejarah berdasar kepentingan militer. Orde Baru kemudian melanjutkan sejarah bercorak militer itu dengan menempatkan orde baru sebagai akhir sejarah. Orde Baru menampilkan diri sebagai puncak yang paling mungkin dicapai oleh negara dan bangsa Indonesia. Sejarah yang demikian menjadi tidak lagi jujur, karena banyak menutupi fakta-fakta dan data-data yang seharusnya ditampilkan, dan sejarah dinarasikan untuk memenangkan satu kepentingan. Kepentingan pribadi yang tampil dalam narasi sejarah mungkin ada pada sejarah yang disusun oleh M. Yamin, di mana dia mencari model di masa lalu bagi keberadaan negara dan bangsa Indonesia saat ini. perspekti sejarah semacam itu jadi nampak seperti membuat jalan lurus, dan kemudian mencari dan menempatkan pristiwa-peristiwa sejarah di sepanjang jalan sejarah. Konsekuensinya adalah sejarah dibuat dengan progresifitas yang tinggi, dan seringkali menghilangkan narasi atas peristiwa yang akan menimbulkan citra negatif.

\section{SIMPULAN}

Berdasarkan hasil kajian dapat disimpulkan bahwa:

1) Peristiwa sejarah dapat diungkapkan melalui dua macam bukti, yaitu bukti tertulis dan bukti lisan. Sejarah konvensional mengenal hanya bukti tertulis yang dianggap 
mempunyai validitas yang bisa dipercaya. Dalam perkembangan selanjutnya, bukti-bukti lisan sebagai salah satu unsur penting dalam penyelidikan sejarah. Sejarah lisan menghadapi persoalan validitas data. Mekanisme cross check menjadi penting, agar pendapat yang ditemukan lebih mendekati kebenaran. Yang perlu diperhataikan juga adalah adanya tradisi lisan, yang darinya dapat diketahui nilai-nilai, sejarah, moral, struktur sosial, yang ada dalam satu masyarakat. Bukti-bukti yang didapatkan harus bisa dikombinasikan sedemikian rupa, dan tidak boleh mengandung kontradiksi di dalamnya.

2) Narasi sejarah harus dibedakan dengan cerita, karena narasi ditulis oleh bukan sejarawan, sehingga banyak ditulis dengan mencampur antara fakta dengan seni dan tidak harus berdasarkan data-data, tetapi imajinasi penulisnya.

3) Sejarah filsafat lebih banyak ditulis oleh orang yang bukan sejarawan, tetapi ahli filsafat. Sejarah pemikiran pada dasarnya dapat dibagi menjadi pemikiran sebagi kerja individu dan pemikiran sebagai tradisi lisan yang diwariskan secara turun temurun.

4) Sejarah berperspektif Indonesia dianggap penting, sayangnya, sejarah nasional Indonesia ditengarai sangat bercorak militer.

\section{DAFTAR PUSTAKA}

Borges, Jorge Luis. 1999. Labirin Impian. Yogyakarta: LKis.

Busro, Muhammad, 2015. "Tradisi Lisan Masyarakat Asli Selatan Purworejo", Makalah tidak diterbitkan, Serang: STIE Banten

Lindsay, Jeniffer. 1989. Klasik, Kitsch, Kontemporer: Sebuah Studi Tentang Seni Pertunjukan Jawa. Yogyakarta: Gadjah Mada University Press.

Lemon, M. C. 1995. The Dicipline of History and The History of Thought. London: Routledge.

Kuntowijoyo. 2003. Metodologi Sejarah. Yogyakarta: Tiara Wacana.

Sumardjo, Jakob. 1992. Perkembangan Teater Modern dan Sastra Drama Indonesia. Bandung: P.T. Citra Aditya Bakti.

Borges, Jorge Luis. 1999. Labirin Impian. Yogyakarta: LKis. 